\title{
Erik Hansen \& Jørn Lund: Kulturens Gesandter. Fremmedordene $i$ dansk. København: Munksgaard, 1994
}

Fremmedordene er velnok den del af det danske sprog som udløser flest debatter. Fremmedordene får på puklen, de er grimme, uforståelige og unødvendige — i alt fald hvis man skal tro flertallet af de læserbreve som handler om sproget. Men det er (næsten) udelukkende de nye engelske ord som vækker så stærke følelser, mens et ord som nervøs ikke opfattes som fremmed. Årsagen er selvfølgelig at dette ord har vi vænnet os til, og det har tilpasset sig det danske sprog.

Fremmedordene er et følsomt område at begive sig ind på, fordi fordomme og æstetiske præferancer blandes med manglende sproghistorisk viden. Så det er ikke specielt forbløffende at netop Erik Hansen og Jørn Lund kaster sig over emnet; hver især har de gjort sig kendt for en stor indsats for sproglig folkeoplysning i en lang række sammenhænge, altid med en prægnant sans for provokerende spidsformuleringer. En sådan er også titlen på deres bog om fremmedordene, Kulturens Gesandter, selvom de har lånt udtrykket fra sprogforskeren Israel Levin. Udtrykket sammenfatter forfatternes syn på fremmedordene som udefra kommende påvirkning, der holder det danske sprog levende og gør det i stand til at udtrykke vore følelser, vor kultur. Uden fremmedord ville det danske sprog være meget fattigt; som de to formulerer det: "Fremmedordene har frelst det danske sprog fra undergang!"

Men foruden at være et forsvar for fremmedordene er bogen en velskrevet gennemgang af de fremmede ords typologi og funktion. Først diskuteres den lingvistiske definition af begrebet fremmedord over for den dagligdags, og problemerne med fremmedordene sættes ind i en kommunikativ sammenhæng. Dernæst gennemgås de forskellige typer af lån: direkte lån, oversættelseslån, betydningslån mfl.; fremmedordenes historie, udtale, stavning og bøjning behandles, og hele bogen sluttes af med en diskussion af den sproglige purisme i Danmark (og Norden).

En af bogens store forcer er forfatternes evne til at belyse nutidens sprogdebat med historisk perspektiv. Hansen \& Lund viser kort hvordan det danske sprog fra år ca. 1100 har været "urent”; allerede fra dette tidspunkt har sproget indeholdt ord fra ikke-germanske sprog, og det som ændrer sig gennem historien er den kilde, hvorfra vi får de nye fremmedord, ikke selve "lånet" som sådant. Vi har lånt fra middelnedertysk, tysk, italiensk, fransk, engelsk for slet ikke at tale om latin og græsk, men ordene tilpasses næsten altid til de danske regler for udtale og bøjning, hvilket hurtigt gør dem til integrerede dele af det danske sprog. Denne evne hos vort sprog til at integrere fremmedordene forklarer også en del af purismens manglende succes i Danmark: skal man være konsekvent og erstatte fremmedordene med nordiske ord, vil en lang række 
ord som vi opfatter som $100 \%$ danske ord forsvinde, mens de nordiske ord ville opfattes som meget fremmede. Forfatternes forslag er at lade markedskræfterne råde: påvirkning udefra $\mathrm{i}$ form af fremmedord vil enten forsvinde igen som kortlivede modefænomener, eller de vil finde deres plads i det danske sprog og udfylde en rolle der. At fors $\emptyset$ ge at rense sproget er at forsøge at bremse en osmose, og fordi spørgsmålet om "fremmedhed" er så speget som det er, kan resultatet blive ufrivilligt komisk, som når Nordisk Sprogsekretariat foreslår det engelske public service erstattet med publikumskontakt — en sammensætning af to latinske udtryk.

Hansens \& Lunds bog er en letlæst håndbog i fremmedordenes typologi og historie, men det er også en opfordring til mere realisme og mindre ideologi i synet på fremmedordene. Egentlig burde de danske aviser sende den som gave til alle læserbrevsskribenter der skuer det danske sprogs undergang i antallet af udenlandske ord i radio og tv...

Orla Vigs $\varnothing$ 